\title{
ADIPOR1 Gene
}

National Cancer Institute

\section{Source}

National Cancer Institute. ADIPOR1 Gene. NCI Thesaurus. Code C103973.

This gene is involved in hormone binding and signal transduction. 